\title{
Performance of Selected Life Insurance Companies - Comparative Analysis
}

\author{
Kiranmayi Patel", Pavan Patel \\ Siva Sivani Institute of Management, Secunderabad, Telangana, India \\ Email address: \\ kiranmayipatel@gmail.com (K. Patel),pavanpateldr@gmail.com (P. Patel) \\ ${ }^{*}$ Corresponding author
}

\section{To cite this article:}

Kiranmayi Patel, Pavan Patel. Performance of Selected Life Insurance Companies - Comparative Analysis. International Journal of Finance and Banking Research. Vol. 7, No. 2, 2021, pp. 51-57. doi: 10.11648/j.ijfbr.20210702.13

Received: November 9, 2020; Accepted: December 9, 2020; Published: March 17, 2021

\begin{abstract}
Insurance industry plays a vital role in the Indian market. Insurance is a mechanism to overcome uncertainty and risk. The concept of insurance has drawn the attention of practitioners, academicians as well as that of the common people. Insurance products are unsought products which people usually do not buy unless and until they are made aware of it. The development of the insurance regulatory and development authority (IRDA) Act in 1999 passed a clear signal to the end of the monopoly of some players in the insurance business. This study makes an attempt to measure the performance of LIC and other three Private Insurance Companies using the CARAMEL model during the period 2012 - 2013 to 2018 - 2019 . These parameters capture the key operations of life insurers. Typically, the overall financial soundness and performance is a summation of the adequate risk management \& the sound inbuilt control system, and effective \& efficient business underwriting. From the result, it is clear that the earning and profitability ratio is the most important indicator of the performance. ANOVA results sum up that there is a significant difference across the four selected life insurance companies with respect to CARAMEL ratios. Thus the null hypothesis is accepted. Thus, this study concludes the investors who are planning to take the life insurance policy can opt for any one of the selected companies.
\end{abstract}

Keywords: CARAMEL, Ratio Analysis, ANOVA, Hypothesis, LIC, SBI, ICICI, HDFC

\section{Introduction}

Human life has always been an uncertain thing. To be secure against unpleasant possibilities always requires the utmost resourcefulness and foresight on the part of man. Man has been accustomed to pray to God for protection and security from time immemorial. In modern days Insurance Companies want the man to pay for protection and security. It is interesting to note that the insurance man says "God helps those who help themselves"; probably he is correct. Life Insurance can be defined as a contract between an insurance policyholder and an insurance company, where the insurer promises to pay a sum of money in exchange for a premium, upon the death of an insured person or after a set period.

The Finance Minister C. D. Deshmukh announced the nationalization of the life insurance business in 1956. The life insurance business was nationalized on 19th January 1956. The Government brought together life insurers under one nationalized monopoly corporation and Life Insurance
Corporation of India was born. In the wave of privatization, since 1991 many private life insurance companies have entered into the insurance industry. As on date, 24 life insurance companies are operating in India including LIC.

Life insurance provides a high life risk cover that keeps the policyholder and his family protected in case of an unfortunate event. Life insurance also safeguards the interest of people who have diminishing incomes with advancing age, people who meet with accidents or for retired people. Life insurance schemes yield better when compared to other investment alternatives. Most of the life insurance schemes, offer bonuses that no other investment scheme can offer. The money invested in life insurance is safe and covers risks. Section $80 \mathrm{C}$ of the Income Tax Act is an effective way for the salaried person to reduce tax liability. Life insurance provides the advantage of taking a policy loan when the policyholder is in desperate need of money. The loan amount that can be taken in a percentage of the cash value or sum assured under policy depending on the policy provisions. Life insurance 
helps the policyholder in life stage planning where he can plan his life's financial goals as per his convenience. It helps the policyholder to plan for your life stage needs. Life Insurance not only provides for financial support in the event of untimely death but also acts as a long term investment. Further to the goals, like children's education, their marriage, building own dream home or planning a relaxed retired life, according to the policy holder's life stage and risk appetite.

\section{Review of Literature}

An attempt is made in this context to review a few of the earlier studies made on the financial performance of LIC of India and other private sector life insurance companies as follows:

Dr. L. Krishna Veni, Karteek Chedadeepu [1] in their study made an attempt to do a comparative analysis on select companies in the insurance industry and application of caramel model. The study allpied CARAMEL model using descriptive statistics and ANOVA to find the financial soundness of the selected insurance companies during 2007 08 to $2016-2017$.

Jayant D. Chandrapal [2] made an attempt to measure the financial soundness of the Indian life insurers (LIC of India and Private Life Insurance Companies (PLIC)) with the help of ratio analysis based on the CARAMEL framework. Financial Soundness indicators indicate the spectacular growth of the Indian life insurance industry. Since LIC of India was found sounder than the PLIC in respect of CARAMEL framework; however, there was a slower growth and some of the indicators such as Management Efficiency shows a decreasing trend in respect of the financial soundness of LIC of India, on the other side PLIC, have improved their position in the area of cost-effectiveness. It is clear from this study that PLIC shows improvement and an increasing trend in the key areas of financial soundness such as Asset Quality and Capital Adequacy (Solvency Margin). This scenario alarms the future challenges to LIC of India and quotes for the stiff competition from the PLIC in the immediate future.

C Kalpana Naidu and C Paramasivan [3] made an attempt to compare LIC and selected private insurance companies in their study. They stated that the Solvency ratio of private life insurers was much better than LIC despite big losses suffered by them. The Lapsation ratio of private insurers was higher than LIC and servicing of death claims was better in case of LIC as compared to private life insurers. This study concludes that the private sector companies are performing better than LIC of India during the period under consideration.

V. N. Parthiban [4] had undertaken the study on life insurers soundness and performance using the CARAMEL model. The financial soundness and performance of life insurers of LIC, SBI, and ICICI Prudential Life are evaluated through the CARAMEL model and the relevant ratios have been financially sound by and large. Further, this study found that the CARAMEL parameters are significantly different between the selected life insurers in India.

Anoop Kumar Singh and Sumbul Fatima [5] made an attempt to evaluate the growth and performance of ICICI Prudential Life Insurance Company, one of the major private sector life insurance companies through certain parameters like net profit, net premium, number of branches, etc. Besides CARAMEL Model has been used to analyze certain ratios like capital to total assets ratio, the net premium to gross premium ratio, etc. These ratios are further statistically tested using the one-sample t-test.

Maraboina Sreedhar Babu [6] has analyzed the performance of the private and public sectors. The results of this study showed that public insurance companies must remain more competitive by achieving better and faster performance compared to public sector insurance companies. During the decay, the private sector market share is growing much faster than the public sector insurance companies.

Manish Dadhich [7] attempted to examine a different investment portfolio of two life insurance companies. This study also attempts to find out how they follow the prevailing norms of investment guideline and to signify the deviation from investment norm. Investments in infrastructure show no significant difference. In approved investment, LIC of India managed its funds but ICICI depicted the significant difference during these five years and invested comparatively in this segment. It is a limited investment in government securities that gives an opportunity to the insurers to invest more funds in approved or high return securities.

Surendra Kumar C. Gulhane [8] has analysed performance of Public and Private Sector Life Insurance Companies and opined that Inspite of privatization of Life Insurance Business in India, Life Insurance Corporation of India still enjoys the dominating position in the Insurance Sector. The study states that the strategies and marketing of Private Sector Life Insurance Companies are unable to break the performance of Life Insurance Corporation of India.

Chaudhary and Kiran [9] observed the current scenario of the life insurance industry in light of some changes and regulations of IRDA. By studying different variables, the results concluded that the life insurance industry expanded tremendously from 2000 onwards in terms of number of offices, number of agents, new business policies, products, premium income, etc.

Gour and Gupta [10] focused on the determination of the solvency ratio of Indian Life insurance companies for the period of 3 years from 2009-10 to 2011-12. It analyzed whether the performance of different companies was similar or there was any significant difference. On the basis of solvency ratio, ranks were assigned to different companies which showed that ICICI found the best among selected companies of the industry followed by Birla Sun Life, SBI, HDFC, and LIC.

Neelaveni [11] evaluated the performance of selected five life insurance companies in terms of various plans and policies on the basis of annual growth rate. The study concluded that Life Insurance Corporation being the public sector was lagging behind due to severe competition from the 
private insurers whereas private life insurance companies have performed well in terms of financial aspects.

Charumathi [12] identified the factors that determine the profitability of life insurers operating in India using the Regression analysis. For this study one public and 22 private players have been considered during a period of three years i.e. 2008-09 to 2010-11. The results conclude that the profitability of life insurers was positively affected by size and liquidity but negatively influenced by leverage, premium growth, and equity capital during the study period.

Kumari [13] analyzed the financial performance of both public and private life insurance industry. For this purpose financial performance was measured with the help of various financial ratios. The results sum up that there had been a significant increase in the overall business performance of the Indian life insurance industry after privatization.

Valeed A. Ansari and Wubshet Fola [14], examined the financial soundness and performance of life insurance companies in India, based on regulatory and supervisory parameters and standards. This study employed CARAMEL model and its parameters capture the key operations of life insurers. This study has taken seven registered life insurers into consideration and examined during the period 2008-09 to 2012-13. CARAMEL model results reveal that; there was a significant difference between capital adequacy, asset quality, management efficiency, earnings \& profitability and liquidity position in private and public life insurance companies.

\section{Objective of the Study}

To compare the financial performance of LIC and three private sector insurance companies like ICICI Prudential. HDFC, SBI Life insurance companies using CARAMEL Model during a period of $2012-2013$ to $2018-2019$.

\section{Statement of Hypothesis}

There is no significant difference between the selected life insurance companies with respect to Total Capital Adequacy
Ratios, Asset quality Ratio, Total Reinsurance and Actuarial Issues Ratios, Total Management Soundness ratios, Total Earning and Profitability Ratios, and Total liquidity ratios.

\section{Research Methodology}

The present study is mainly based on secondary data. Data and information have been extracted from Annual Reports of LIC of India and the balance sheets of selected private sector companies dealing with Life Insurance during the period $2012-2013$ to $2018-2019$.

\subsection{Tools and Technique of Analysis}

The tools which are used for this study are different ratios that are used in the CARAMEL Model. The CARAMEL parameters are statistically tested with the help of statistical tool ANOVA. CARAMEL's framework consists of different ratios like Capital adequacy, Asset quality, Reinsurance, Adequacy of claims and actuarial, Management soundness, Earnings and profitability, Liquidity and Sensitivity to market risk.

\subsection{Sampling Area}

To measure the financial performance of different companies considered for this study like Life Insurance Corporation of India and ICICI Prudential, HDFC and SBI Life Insurance.

\subsection{Period of Study}

This study is made for a period of 7 years i.e., $2012-2013$ to $2018-2019$.

\subsection{Significance of the Study}

To understand the financial performance and soundness of the public sector and private sector life insurance companies in India and to analyze the financial soundness of life insurance companies, this study is very crucial.

Table 1. Capital Adequacy.

\begin{tabular}{|c|c|c|c|c|c|c|c|c|}
\hline Name of life insurer & Ratios & 2012-13 & 2013-14 & 2014-15 & 2015-16 & 2016-17 & 2017-18 & 2018-19 \\
\hline \multicolumn{9}{|l|}{ Public Sector } \\
\hline LIC & $\begin{array}{l}\text { Solvency ratio } \\
\text { Capital to total asset }\end{array}$ & $\begin{array}{l}1.54 \\
0.0003\end{array}$ & $\begin{array}{l}1.54 \\
0.0004\end{array}$ & $\begin{array}{l}1.54 \\
0.0003\end{array}$ & $\begin{array}{l}1.54 \\
0.0003\end{array}$ & $\begin{array}{l}1.54 \\
0.0003\end{array}$ & $\begin{array}{l}1.54 \\
0.0003\end{array}$ & $\begin{array}{l}1.54 \\
0.0003\end{array}$ \\
\hline \multicolumn{9}{|l|}{ Private Sector } \\
\hline SBI & $\begin{array}{l}\text { Solvency ratio } \\
\text { Capital to total asset }\end{array}$ & $\begin{array}{l}2 \\
0.041\end{array}$ & $\begin{array}{l}2.11 \\
0.046\end{array}$ & $\begin{array}{l}2.15 \\
0.052\end{array}$ & $\begin{array}{l}2.23 \\
0.052\end{array}$ & $\begin{array}{l}2.16 \\
0.048\end{array}$ & $\begin{array}{l}2.12 \\
0.054\end{array}$ & $\begin{array}{l}2.04 \\
0.047\end{array}$ \\
\hline ICICI & $\begin{array}{l}\text { Solvency ratio } \\
\text { Capital to total asset }\end{array}$ & $\begin{array}{l}3.27 \\
0.068\end{array}$ & $\begin{array}{l}3.71 \\
0.069\end{array}$ & $\begin{array}{l}3.96 \\
0.069\end{array}$ & $\begin{array}{l}3.72 \\
0.067\end{array}$ & $\begin{array}{l}3.36 \\
0.079\end{array}$ & $\begin{array}{l}3.2 \\
0.079\end{array}$ & $\begin{array}{l}2.8 \\
0.079\end{array}$ \\
\hline HDFC STANDARD & $\begin{array}{l}\text { Solvency ratio } \\
\text { Capital to total asset }\end{array}$ & $\begin{array}{l}1.8 \\
0.066 \\
\end{array}$ & $\begin{array}{l}1.72 \\
0.054\end{array}$ & $\begin{array}{l}1.88 \\
0.068\end{array}$ & $\begin{array}{l}2.17 \\
0.057\end{array}$ & $\begin{array}{l}1.364 \\
0.055 \\
\end{array}$ & $\begin{array}{l}0.65 \\
0.053 \\
\end{array}$ & $\begin{array}{l}0.47 \\
0.067 \\
\end{array}$ \\
\hline
\end{tabular}

\section{Data Analysis and Result Discussion}

Table 1 shows the capital adequacy position of selected life insurers in India during the period of study. Capital is considered to protect the insured and promote the soundness of the financial system; it also indicates whether the insurer has enough capital to absorb losses arising from claims. Then the 'Capital Adequacy Ratio' is the key indicator of an insurer's financial dependability position. As per the IRDA regulations, 
insurers have asked to maintain solvency margin of 1.5 i.e. excess of assets over liabilities, monitored on a quarterly basis, further IRDA issues registration to those companies only having capital of a minimum of Rupees one billion. LIC just managed its fate at nearly the minimum statutory requirements; the ratio remained at 1.54 for the last five consecutive years; even though it's slightly higher than the minimum statutory requirements ratio of 1.5 . The private life insurer ICICI Prudential capital adequacy ratios have shown an increasing trend that ranges from 3.27 to 2.80 . The SBI life insurance company capital adequacy ratio has increased in the early years of the study but varied in the later years. But HDFC standard life insurance company has recorded an increasing trend in the beginning but later shown a gradual decline.

Table 2. Asset quality ratio.

\begin{tabular}{|c|c|c|c|c|c|c|c|c|}
\hline Name of life insurer & Ratios & 2012-13 & 2013-14 & 2014-15 & 2015-16 & 2016-17 & 2017-18 & 2018-19 \\
\hline LIC & $\mathrm{AQR}$ & 0.0125 & 0.0118 & 0.0006 & 0.0115 & 0.0006 & 0.0225 & 0.0342 \\
\hline SBI & $\mathrm{AQR}$ & 0.0003 & 0.0015 & 0 & 0.0015 & 0.0003 & 0.0012 & 0.0014 \\
\hline ICICI & $\mathrm{AQR}$ & 0.0001 & 0.0018 & 0.0001 & 0.002 & 0.0019 & 0.0026 & 0.0015 \\
\hline HDFC STANDARD & AQR & 0.0436 & 0.0548 & 0.0686 & 0.0832 & 0.1288 & 0.3036 & 0.4186 \\
\hline
\end{tabular}

Table 2 represents the management ratios of LIC, SBI and ICICI prudential and HDFC standard from 2012 - 2013 to 2018 - 2019. LIC has increased from 0.0125 in 2012-13 to $0.03422018-19$ and ICICI Prudential has also witnessed a gradual decline from 0.0026 to 0.0015 during the study period. The HDFC standard has recorded a gradual growth during the study period. The SBI Life has witnessed a continuously increasing expense to their business operations from 0.0003 to 0.0014 during the period under consideration but recorded a decline in the last year.

Table 3. Reinsurance and actuarial related issues.

\begin{tabular}{|c|c|c|c|c|c|c|c|c|}
\hline Name of life Insurer & Risk-Return Ratio & 2012-13 & 2013-14 & 2014-15 & 2015-16 & 2016-17 & 2017-18 & 2018-19 \\
\hline LIC & RRR & 0.9994 & 0.9996 & 0.999 & 0.9994 & 0.9992 & 0.9992 & 0.9033 \\
\hline SBI & RRR & 0.9972 & 0.996 & 0.9935 & 0.9924 & 0.9932 & 0.9899 & 0.9923 \\
\hline ICICI & RRR & 0.9964 & 0.9933 & 0.9911 & 0.9883 & 0.9905 & 0.9914 & 0.9911 \\
\hline
\end{tabular}

From Table 3, the risk retention ratio indicates that the life insurance sector retained the risk at their own destiny, which can be witnessed by the slightly increasing trend during the study period from $2012-2013$ to $2018-2019$, given that they do not rely considerably on reinsurance as non-life insurers do. Therefore insignificant gap is seen between Gross Written Premium (GWP) and Net Premium which indicates the risk passed onto the reinsurers is negligible. In other words, the life insurers passed on to reinsurance only 1.19 percent of the total direct premium. From table 3 , it is observed that the life insurers preferred retaining risk at their own destiny to passing the risk onto the reinsurers so as to boost up their profits by reducing the transaction costs and sharing of premium income with reinsurers, during the study period. In this study, Public sector Life Insurance Company LIC has maintained the thumb rule of 1.19 percent. It maintained a below growth. As compared to private sector life insurance companies SBI, ICICI Prudential, HDFC companies have maintained the below the thumb rule and there is a continuous growth in the risk retention ratio for a particular period.

Table 4. Management Soundness.

\begin{tabular}{|c|c|c|c|c|c|c|c|c|}
\hline Name of life Insurer & Operating expense Ratios & 2012-13 & 2013-14 & 2014-15 & 2015-16 & 2016-17 & 2017-18 & 2018-19 \\
\hline LIC & OER & 0.0835 & 0.0735 & 0.08 & 0.101 & 0.0941 & 0.0857 & 0.1096 \\
\hline SBI & OER & 0.5863 & 0.078 & 0.1101 & 0.1667 & 0.1601 & 0.1221 & 0.1545 \\
\hline ICICI & OER & 0.4397 & 0.3167 & 0.3552 & 0.285 & 0.3289 & 0.3477 & 0.3787 \\
\hline HDFC STANDARD & OER & 0.1661 & 0.1245 & 0.1074 & 0.1062 & 0.1004 & 0.1147 & 0.1227 \\
\hline
\end{tabular}

The above table 4 reveals that management ratios of LIC, SBI, I CICI Prudential and HDFC Standard for the period $2012-13$ to 2018 - 19. The SBI Life has witnessed continuously increasing expenses to their business operations volume during the study period while the ICICI Prudential and the LIC have also recorded fluctuating expenses to their business operations volume. HDFC Standard has there is a continuous decrease in the $2014-15$ and an increase in the $2017-18$.

Table 5. Earnings and profitability ratio.

\begin{tabular}{|c|c|c|c|c|c|c|c|c|}
\hline Name of life insurer & Ratios & 2012-13 & 2013-14 & 2014-15 & 2015-16 & 2016-17 & 2017-18 & 2018-19 \\
\hline \multirow{2}{*}{ LIC } & ROE & 234.36 & 213.13 & 234.38 & 245.38 & 246.48 & 244.55 & 245.38 \\
\hline & ROA & 0.0009 & 0.001 & 0.0009 & 0.0008 & 0.0009 & 0.0007 & 0.0009 \\
\hline \multirow{2}{*}{ SBI } & ROE & 0.3663 & 0.5558 & 0.6222 & 1.27 & 1.21 & 1.07 & 1.03 \\
\hline & ROA & 0.0093 & 0.0119 & 0.1109 & 1.27 & 1.21 & 1.07 & 1.03 \\
\hline \multirow{2}{*}{ ICICI } & ROE & 0.5654 & 0.9687 & 1.0469 & 1.2713 & 1.2636 & 1.16 & 1.16 \\
\hline & ROA & 0.0115 & 0.0193 & 0.0201 & 0.0209 & 0.0169 & 0.017 & 0.22 \\
\hline SHDFC STANDARD & ROE & -0.0493 & 0.1359 & 0.2263 & 0.2363 & 0.2243 & 0.24 & 0.22 \\
\hline
\end{tabular}

Note: ROE - Return on equity, ROA - Return on Assets 
Table 5 highlights the Earning and profitability Ratios of LIC, SBI, ICICI Prudential and HDFC Standard for the period under consideration 2012 - 2013 to 2018 - 2019 . Earnings are one of the key sources of inbuilt long term capital base for an insurance company. Low profitability may signal fundamental problems of the insurer and may consider a leading indicator for solvency problems. Therefore, considerable attention has given to this area so that the most important indicators of earnings and profitability are included in this study for life insurers' under review. Thus these are the
Expense Ratio, ROE, and ROA. The ROE is measured as the ratio of net profit to equity shows that the net profits that are returned to shareholders, higher the return on equity, the more profitable the insurer has become and the possibility of enhanced dividends to shareholders. The ROA is measured as the ratio of net profit on assets; thus the study included this ratio as a proxy to investment ratio as an indicator of the effectiveness of their investment policies by and large since Life Insurance Company has been functioning to a large extent as asset managers.

Table 6. Liquidity ratio.

\begin{tabular}{|c|c|c|c|c|c|c|c|c|}
\hline Name of life insurer & Ratios & 2012-13 & 2013-14 & 2014-15 & 2015-16 & 2016-17 & 2017-18 & 2018-19 \\
\hline \multirow{2}{*}{ LIC } & LA to $\mathrm{LL}$ & 3.723 & 3.087 & 5.859 & 3.753 & 3.619 & 3.004 & 3.06 \\
\hline & LA to TA & 0.048 & 0.072 & 0.094 & 0.013 & 0.02 & 0.032 & 0.051 \\
\hline \multirow{2}{*}{ SBI } & LA to LL & 0.777 & 2.415 & 2.399 & 2.753 & 2.619 & 2.004 & 2.06 \\
\hline & LA to TA & 0.034 & 0.068 & 0.065 & 0.043 & 0.052 & 0.57 & 0.627 \\
\hline \multirow{2}{*}{ ICICI } & LA to LL & 0.417 & 0.537 & 0.648 & 0.634 & 0.484 & 0.628 & 0.635 \\
\hline & LA to TA & 0.01 & 0.013 & 0.018 & 0.026 & 0.002 & 0.003 & 0.002 \\
\hline HDFC STANDARD & LA to LL & 0.804 & 0.852 & 0.977 & 0.082 & 0.046 & 0.045 & 0.049 \\
\hline
\end{tabular}

Note: LA to LL - Liquid Assets to Total Liabilities, LA to TA Liquid Assets to Total Assets

Table 6 highlights Liquid ratios of LIC, SBI, ICICI prudential for the period 2012 - 2013 to 2018 - 2019 . Liquidity is the sixth and last component of the CARAMEL framework for life insurers but not the least even if their liquidity of liabilities is relatively predictable backed through their long-term obligations. The 1 st ratio presented in table 6 represents the Current Ratio. The results indicate that the life insurer's ability to meet the short-term obligations is steady improving year on year basis during the study period, given that their inherently long-term obligations. The private insurer of ICICI Prudential and HDFC life insurance Company limited have recorded the current ratio below the rule of thumb, that is, at least a 1:1 ratio, during the study period. The 2 nd ratio, liquid assets to total assets reflects the financial assets position in the total assets of an insurer.

Null Hypothesis: (Ho)

Based on the above ratios, this study makes further attempts to test the following hypothesis. There is no significant difference among the selected life insurance companies with respect to Total Capital Adequacy Ratios, Asset quality Ratio, Total Reinsurance and Actuarial Issues Ratios, Total Management Soundness ratios, Total Earning and Profitability Ratios, and Total liquidity ratios.

Table 7. Descriptive Statistics.

\begin{tabular}{lllll}
\hline Ratio & & Mean & Standard Deviation & Standard Error \\
\hline & LIC & 0.770157 & $1.88982 \mathrm{E}-05$ & $7.14286 \mathrm{E}-06$ \\
Total capital adequacy & SBI & 1.082143 & 0.040065274 & 0.01514325 \\
& ICICI & 1.752143 & 0.194118674 & 0.073369962 \\
& HDFC & 0.748143 & 0.32321996 & 0.122165662 \\
& Total & 4.352586 & 0.557422807 & 0.210686017 \\
& LIC & 0.013386 & 0.011903141 & 0.004498964 \\
Asset Quality ratio & SBI & 0.000886 & 0.000656832 & 0.000248259 \\
& ICICI & 0.001429 & 0.000965599 & 0.000364962 \\
& HDFC & 0.157314 & 0.14565145 & 0.055051073 \\
& Total & 0.173014 & 0.159177021 & 0.060163259 \\
Total reinsurance and Actuarial related issues & LIC & 0.985586 & 0.036285095 & 0.013714477 \\
& SBI & 0.9935 & 0.002437212 & 0.000921179 \\
& ICICI & 0.991729 & 0.00253161 & 0.000956859 \\
& HDFC & 0.993571 & 0.001644906 & 0.000621716 \\
Total Management Soundness Ratio & Total & 3.964386 & 0.042898821 & 0.01621423 \\
& LIC & 0.089629 & 0.012609482 & 0.004765936 \\
& SBI & 0.196829 & 0.174624766 & 0.066001958 \\
& ICICI & 0.350271 & 0.049464961 & 0.018695998 \\
Total Earnings and Profitability Ratio & HDFC & 0.120286 & 0.022036442 & 0.008328992 \\
& Total & 0.757014 & 0.258735652 & 0.097792884 \\
& LIC & 118.8333 & 6.013253306 & 2.272796117 \\
& SBI & 0.774029 & 0.47243288 & 0.178562845 \\
& ICICI & 0.5544 & 0.135489025 & 0.051210038 \\
& HDFC & 0.110579 & 0.067584002 & 0.025544352 \\
\hline
\end{tabular}




\begin{tabular}{lllll}
\hline Ratio & & Mean & Standard Deviation & Standard Error \\
\hline & Total & 120.2723 & 6.688759214 & 2.528113351 \\
& LIC & 1.888214 & 0.50533552 & 0.190998874 \\
Liquidity Ratio & SBI & 1.177571 & 0.345490162 & 0.130583007 \\
& ICICI & 0.289786 & 0.046899589 & 0.017726378 \\
& HDFC & 0.294 & 0.182366846 & 0.068928189 \\
& Total & 3.649571 & 1.080092118 & 0.408236448 \\
\hline
\end{tabular}

Table 8. Results of ANOVA.

\begin{tabular}{|c|c|c|c|c|c|c|}
\hline & Source of Variation & SS & Df & MS & $\mathbf{F}$ & P-value \\
\hline \multirow{4}{*}{ Total capital adequacy } & Between Groups & 0.278265 & 3 & 0.092755 & 0.239769 & 0.866263 \\
\hline & Within Groups & 3.094802 & 8 & 0.38685 & & \\
\hline & Total & 3.373067 & 11 & & & \\
\hline & Between Groups & 0.030196 & 3 & 0.010065 & 12.75411 & 0.002042 \\
\hline \multirow{3}{*}{ Asset Quality ratio } & Within Groups & 0.006314 & 8 & 0.000789 & & \\
\hline & Total & 0.03651 & 11 & & & \\
\hline & Between Groups & 0.000393 & 3 & 0.000131 & 0.000406 & 0.999988 \\
\hline \multirow[t]{3}{*}{ Total Reinsurance and Actuarial Issues Ratio } & Within Groups & 2.581215 & 8 & 0.322652 & & \\
\hline & Total & 2.581608 & 11 & & & \\
\hline & Between Groups & 0.030201 & 3 & 0.010067 & 0.907113 & 0.479272 \\
\hline \multirow{3}{*}{ Total Management Soundness Ratio } & Within Groups & 0.088784 & 8 & 0.011098 & & \\
\hline & Total & 0.118985 & 11 & & & \\
\hline & Between Groups & 3990.029 & 3 & 1330.01 & 1.212329 & 0.366094 \\
\hline \multirow{3}{*}{ Total Earnings and Profitability Ratio } & Within Groups & 8776.56 & 8 & 1097.07 & & \\
\hline & Total & 12766.59 & 11 & & & \\
\hline & Between Groups & 1.079294 & 3 & 0.359765 & 1.244811 & 0.355968 \\
\hline \multirow{2}{*}{ Liquidity Ratio } & Within Groups & 2.312093 & 8 & 0.289012 & & \\
\hline & Total & 3.391387 & 11 & & & \\
\hline
\end{tabular}

From Table 8 it is evident that there is a significant difference across the four life insurance companies selected for this study namely LIC, SBI, ICICI and HDFC Standard with respect to CARAMEL Ratios.

It is clear from the table 8 that the p-value of Total Solvency Ratio (0.86), Total Reinsurance and Actuarial Issues Ratio (0.99), Total Management Sound Ratio (0.48), Total Earnings and Profitability Ratio (0.37) and Liquidity ratio (0.35) are more than 0.01 (except Asset Quality Ratio) thus the null hypothesis is accepted at $1 \%$ level of significance. Thus from the above analysis, it is clear that there is no significant difference across the selected four life insurance companies with respect to the CARAMEL model.

\section{Conclusions}

It is clear that LIC has just managed its fate at nearly the minimum statutory requirements as per the IRDA regulations; the capital adequacy ratio remained at 1.54 for the last five consecutive years; even though it's slightly higher than the minimum statutory requirements ratio of 1.5. The private life insurer, ICICI Prudential capital adequacy ratios have been increasing trend, however, the SBI life insurance company's capital adequacy ratio has declined from 2014-2019 and later it varied between 0.052 to 0.047 . HDFC standard life insurance company indicated a gradual decline from during the study period. It also reveals that the Management ratio of LIC has increased from 0.0125 in 2013 to 0.0342 2019. But the ICICI Prudential has witnessed a gradual decline from 0.0018 to 0.0015 during the period under consideration and there is an increase in 2016 as 0.0026. The HDFC standard has growth from 2013 to 2019.
It is evident that the risk retention ratio indicates that the life insurance sector retained the risk at their own destiny, which can be witnessed by the slightly increasing trend during the study period from 2012 - 2013 to $2018-2019$, given that they do not rely considerably on reinsurance as non-life insurers do. Hence, an insignificant gap is found between Gross Written Premium (GWP) and Net Premium which indicates the risk passed onto the reinsurers is negligible. In other words, the life insurers passed on to reinsurance only 1.19 percent of the total direct premium.

From this study, it is observed that the life insurers preferred retaining risk at their own destiny to passing the risk onto the reinsurers so as to boost up their profits by reducing the transaction costs and sharing of premium income with reinsurers, during the study period. In this study, the Public Sector Life insurance company LIC has maintained the thumb rule of 1.19 percent. It maintained a below growth when compared to private sector life insurance companies SBI, ICICI Prudential, HDFC life insurance companies have maintained the below the thumb rule and there is a continuous growth in the risk retention ratio for a particular period.

The results reveal that management ratios of SBI Life during the period of study have witnessed continuously increasing expenses to their business operations volume while the ICICI Prudential and the LIC has recorded fluctuating expenses to their business operations volume. It has been increased from 2013 to 2016 and there is a deemed decrease from 2017 to 2019 . HDFC Standard has shown that there is a continuous decline in 2017. But it has shown that there is an increase in the years 2016 to 2017 . The peer and industry average trend ratio indicated that in general the 
operation expenses decreasing from year on year basis, given still the highest. The SBI Life Insurance has witnessed continuously decreasing trend, however, SBI Life holds the first position in the sector by recording good business performance, whereas the LIC has shown surging up and down business performance during the study period.

It is also clear from the study that considerable attention was given to the Earning and profitability Ratios as the most important indicators of the life insurers' selected for the study like LIC, SBI and ICICI prudential, HDFC Standard life insurance company from during the study period from 2012 2013 to 2018 - 2019. Earnings are one of the key sources of inbuilt long term capital base for an insurance company. Low profitability may signal fundamental problems of the insurer and may consider a leading indicator for solvency problems.

Liquidity is the sixth and last component of the CARAMEL framework for life insurers but not the least even if their liquidity of liabilities is relatively predictable backed through their long-term obligations.

From the entire study, it can be summed up that the life insurer's ability to meet the short-term obligations is steadily improving on year on year basis during the study period, given that their inherently long-term obligations. The private insurer of ICICI Prudential and HDFC life insurance Company limited was recorded the current ratio below the rule of thumb, that is, at least a 1:1 ratio, during the study period. The 2 nd ratio, liquid assets to total assets reflects the financial assets position in the total assets of an insurer. The ratio analysis, to some extent, supports the previous discussion made under the current ratio, thus both the peer and industry average was fluctuating down during the study period.

Finally, it can be concluded that the investors who are planning to take the life insurance policy can take the policy from any life insurance company considering financial performance based on the CARAMEL model.

\section{References}

[1] Dr. L. Krishna Veni, Karteek Chedadeepu (2018) Application Of Caramel Model To Life Insurance Companies In India - A Comparative Analysis, Vol. 8, Issue 8 (1), August 2018, ISSN: 2249-2496 Impact Factor: 7.081.

[2] Jayant D. Chandrapal, (2017) Evaluation of financial soundness indicators of Indian life insurance industry: LIC of India vs. Private Life Insurance Companies, International Journal of Research in Computer Application \& Management, Volume no. 7, issue no. 07 July, pp - 68, ISSN 2231-1009.
[3] C Kalpana Naidu and Dr. C Paramasivan (2015), A comparative study of public \& private life insurance companies in India, International Journal of Multidisciplinary Research Review, Vol. 1, Issue - 7, Sep -2015, E- ISSN 2395-1885, ISSN -2395-1877.

[4] V. N. Parthiban, Evaluation of Financial Position and Performance of Selected Life Insurers in India through the Caramel Model, Splint International Journal of Professionals, ISSN 2349-6045, Vol. -2, No. -4.

[5] Anoop Kumar Singh and Sumbul Fatima, (2017), Performance Appraisal of ICICI Prudential Life Insurance Company Limited Using the Caramel Model, The Indian Journal of Commerce Vol. 70, No. 2, April-June 2017, 85-91.

[6] Maraboina Sreedhar Babu (2015), A Comparative Study of Public and Private Insurance Sector Performance, International Journal of Arts and Science Research. 2 (2), 2015, 56-62 July - December, ISSN: 2393-9532. www.ijasrjournal.com.

[7] Manish Dadhich (2015), A Comparative Study of Investment Portfolio of Life fund of LIC of India and ICICI Prudential Life Insurers, International Journal of Research in Economics and Social Sciences (IJRESS), Vol. 6 Issue 10, October 2016. 229 - 238. ISSIN (O) 2249-7382, Impact factor: 6.225, Thomson Reuters ID: L - 5236-2015.

[8] Surendra Kumar C. Gulhane, Public \& Private Life Insurance Companies in India - A Comparative Study, Golden Research Thoughts, ISSN:-2231-5063, Volume 2, Issue. 7, Jan. 2013.

[9] Sonika Chaudhary and P. Kiran (2011), Life Insurance Industry in India - Current Scenario, IJMBS Vol. 1, Issue 3, September 2011.146-150. ISSN: 2330-9519.

[10] Bhuvnesh Gour and M. C. Gupta (2012), A Review on Solvency Margin in Indian Insurance Companies, University of Rajasthan, Jaipur-India, IJRRR, Vol. II, ISSN 2277-8322.

[11] Neelaveni V (2012), Financial Performance of Life Insurance Companies and Products, ZIJBEMR, Vol. 2, Issue 3, 233-258.

[12] B. Charumathi (2011), On the Determinants of Profitability of Indian Life Insurers - An Empirical Study, Proceedings of the World Congress on Engineering 2012 Vol I WCE 2012, July 4 - 6, 2012, London, U. K.

[13] Kumari T. H. (2013), Performance Evaluation of Indian Life Insurance Industry in Post Liberalization, IJSSAH, Vol. 1 (1), pp - 7-14.

[14] Valeed A. Ansari and Wubshet Fola (2014), Financial Soundness and Performance Life Insurance Companies in India, IJR, Vol - 1, Issue - 8 September 2014 ISSN 2348 6848 . 